\title{
Analisis Korespondensi Berganda terhadap Faktor-Faktor yang Mempengaruhi Pilihan Masyarakat kepada Calon Bupati/Wakil Bupati
}

\author{
MUNAWAR ${ }^{1}$, MARZUKI ${ }^{2}$, HAFNANI ${ }^{3}$, MUHAMMAD IQBAL ${ }^{4}$ \\ 1,2,4Program Studi Statistika, Fakultas MIPA, Universitas Syiah Kuala \\ 3Program Studi Matematika, Fakultas MIPA, Universitas Syiah Kuala \\ email: munawar@unsyiah.ac.id
}

\begin{abstract}
ABSTRAK
Analisis korespondensi berganda merupakan teknik analisis multivariat untuk melihat hubungan kedekatan beberapa variabel tidak bebas katagorik. Penelitian bertujuan menggunakan analisis ini untuk melihat faktor-faktor yang mempengaruhi pilihan masyarakat terhadap salah satu kandidat pasangan calon kepala daerah di salah satu kabupaten di Aceh pada Pemilihan Kepala Daerah Tahun 2018. Data yang digunakan merupakan hasil survei yang dilakukan oleh salah satu lembaga survei di Banda Aceh. Jumlah sampel adalah sebanyak 890 responden dengan teknik pengambilan sampel adalah stratified random sampling dan desa sebagai strata. Variabel yang dikaji sebanyak lima, yaitu usia, pendidikan terakhir, pekerjaan utama, dan pasangan calon yang dipilih serta alasan memilihnya. Pasangan calon kepala daerah yang menjadi pilihan adalah sebanyak 4 pasangan. Variabel yang mempengaruhi adalah pendidikan terakhir pemilih dan faktor yang menarik dari kandidat bagi pemilih. Dua variabel lain, yaitu usia dan pekerjaan pemilih tidak berhubungan dengan pilihan masyarakat terhadap pasangan calon. Pasangan calon yang terpilih disebabkan 4 faktor yaitu sering berinteraksi dengan rakyat, berkomitmen terhadap ekonomi kerakyatan, visi, misi, dan program bagus, dan faktor lainnya.
\end{abstract}

Kata kunci: analisis korespondensi, kepala daerah, pemilihan umum, stratified random sampling.

\begin{abstract}
Multiple correspondence analysis is a multivariate analysis technique to see the close relationship between several non-categorical variables. The research aims to use this analysis to look at the factors that influence community choice of one of the candidates for regional head candidates in one district in Aceh in the Regional Head Election in 2018. The data used is the result of a survey conducted by one of the survey institutes in Banda Aceh. The number of samples is 890 respondents with the sampling technique is stratified random sampling and villages as strata. The variables studied were five, namely age, last education, main occupation, and the candidate pair selected and the reasons for choosing it. The candidate pairs of regional head candidates that are chosen are as many as 4 pairs. The influencing variable is the voter's last education and the interesting factor of the candidate for voters. Two other variables, namely age and occupation of the voter are not related to people's choice of the candidate pair. The candidate pair chosen is due to 4 factors, namely frequent interaction with the people, commitment to the people's economy, vision, mission, and good programs, and other factors.
\end{abstract}

Keywords: correspondence analysis, regional head, general election, stratified random sampling.

\section{PENDAHULUAN}

Data multivariat adalah data beberapa variabel yang didapat dari sebuah individu (Marzuki dan Hafnani, 2014). Analisis korespodensi berganda merupakan salah satu metode dalam analisis data multivariat. Kategori-kategori yang mirip digabung ke dalam satu variabel untuk mereduksi jumlah kategori dalam variabel (Kesuma dkk, 2019). Metode penggabungan dengan 
analisis korespondensi ini merupakan perluasan dari analisis komponen utama untuk data kategorik. Di Indonesia terdapat agenda negara atau daerah berupa pemilihan umum (pemilu) legislatif atau pemilihan pimpinan negara bahkan pemilihan kepala daerah. Analisis ini diaplikasikan dalam fenomena pemilihan ini, yaitu melihat faktor-faktor yang mempengaruhi pilihan masyarakat terhadap salah satu kandidat pasangan calon kepala daerah seperti pasangan bupati dan wakil bupati. Faktor-faktor tersebut biasanya mempunyai kategorikategori yang mirip.

Tahun 2018 merupakan tahun pemilihan kepala daerah (pilkada) di 3 wilayah Aceh. Seluruh rakyat di wilayah ini memilih pimpinan daerah kabupaten/kota sesuai dengan pilihannya. Sebelum pilkada dilaksanakan, berbagai langkah-langkah ditempuh, baik dari pihak kandidat pasangan calon, maupun dari berbagai lembaga swadaya sebagai pengontrol jalannya pemilu. Kandidat pasangan calon bupati/wakil bupati atau walikota/wakil walikota, maupun dari berbagai lembaga swadaya melakukan survei elektabilitas dan preferensi masyarakat sebelum pelaksanaan kampanye pilkada dengan tujuan untuk melihat peluang terpilih dari masingmasing kandidat pasangan calon.

Sebuah survei ini dilakukan pada salah satu kabupaten di Aceh yang pada tahun 2018 melakukan pilkada. Survei ini dilakukan oleh salah satu lembaga survei di Banda Aceh. Salah satu tujuan dari survei tersebut adalah untuk melihat segmentasi dari pemilih terhadap pilihannya dan penyebaran pilihan pasangan calon bupati/wakil bupati. Selain itu, juga dilakukan identifikasi faktor-faktor yang mempengaruhi pilihan pasangan calon.

Faktor-faktor yang berhubungan dengan pilihan pasangan calon bupati/wakil bupati pada hasil survei yang dilakukan itu ingin dideskripsikan dan diidentifikasi dalam tulisan ini. Variabel yang dikaji sebanyak 5 yaitu usia pemilih, pendidikan terakhir pemilih, pekerjaan utama pemilih, pilihan pasangan calon yang layak menurut pemilih, dan alasan yang menjadi faktor pemilih memilih pasangan calon.

\section{DATA DAN METODE}

Data yang digunakan merupakan hasil survei preferensi dan elektabilitas masyarakat terhadap calon bupati/wakil bupati di salah satu kabupaten di Aceh. Jumlah sampel yang ditargetkan sebanyak $n=1000$ responden. Teknik pengambilan sampel yang digunakan adalah sampel acak bertingkat dengan kecamatan dan desa digunakan sebagai tingkat (strata). Tingkat 1 terdapat 8 kecamatan, sedangkan tingkat 2 mempunyai jumlah desa yang berbeda-beda untuk tiap kecamatan. Penentuan jumlah sampel pada setiap tingkat digunakan persamaan alokasi sebanding, yaitu $n_{i}=\left(N_{i} / N\right) x n$ dengan $n_{i}$ adalah jumlah sampel yang terpilih untuk tiap tingkat, $N_{i}$ adalah jumlah daftar pemilih tetap (DPT) tiap tingkat, dan $N$ dan jumlah DPT kabupaten yang dijadikan objek penelitian ini. DPT ini merupakan DPT untuk pemilihan Gubernur Aceh tahun 2015. Jumlah sampel yang terambil berkisar antara 1 orang hingga 30 orang untuk setiap desanya. Data yang dianalisis merupakan data yang lengkap yaitu data yang berasal dari 890 responden.

Prosedur penelitian ini adalah sebagai berikut:

1) Melakukan analisis deskriptif data survei preferensi dan elektabilitas calon bupati/wakil bupati.

2) Melakukan uji kebebasan untuk variabel pilihan masyarakat terhadap calon bupati/wakil bupati dengan 4 variabel lainnya dengan menggunakan uji Khi-Kuadrat $\left(X^{2}\right)$.

3) Dari variabel yang berpengaruh terhadap variabel pilihan masyarakat terhadap calon bupati/wakil bupati, dilakukan penguraian nilai singular untuk mengetahui nilai variabilitas data asli yang dijelaskan oleh setiap dimensi yang dihasilkan.

4) Membuat plot korespondensi berganda menggunakan perangkat lunak Rstudio.

5) Mengamati kategori dari setiap variabel yang saling berdekatan untuk mengidentifikasi karakteristik masyarakat berdasarkan pilihan masyarakat terhadap calon bupati/wakil bupati.

\section{DESKRIPSI DATA}

Pilkada ini diikuti oleh 4 pasang calon bupati/wakil bupati. Survei yang dilakukan adalah preferensi dan elektabilitas pemilihan bupati/wakil bupati. Karakteristik pemilih dalam 
penelitian ini berupa usia pemilih yang dapat dilihat pada Gambar 1, pendidikan terakhir dan pekerjaan utama pemilih yang ditampilkan pada Gambar 2 dan Gambar 3. Hasil pilihan masyarakat terhadap keempat pasang calon bupati/wakil bupati ditampilkan pada Gambar 4 . Alasan yang menjadi faktor pemilih memilih calon bupati/wakil bupati ditampilkan pada Gambar 5.

Usia pemilih paling dominan adalah berusia 31-40 tahun (36\%), 41-50 tahun (27\%), dan 21-30 tahun (17\%). Pemilih pemula (17-20 tahun) sebanyak $2 \%$. Sisanya adalah pemilih dengan rentan usia lebih dari 51 tahun (18\%).

Pendidikan terakhir pemilih yang paling banyak, seperti terlihat pada Gambar 2 adalah SMA/SMK/MA (P3) yaitu sebesar 45,17\%. Pendidikan terakhir pemilih yang SMP/MTs (P2) sebanyak 24,38\%, selanjutnya S1 (P6) sebanyak 12,47\%, SD/MI (P1) sebanyak 10,79\%, D3/D4 (P5) sebanyak 5,39\%, Tidak Sekolah (P8) sebanyak 1,35\%, D1/D2 (P4) sebanyak 0,34\%, dan S2 (P7) hanya $0,11 \%$.

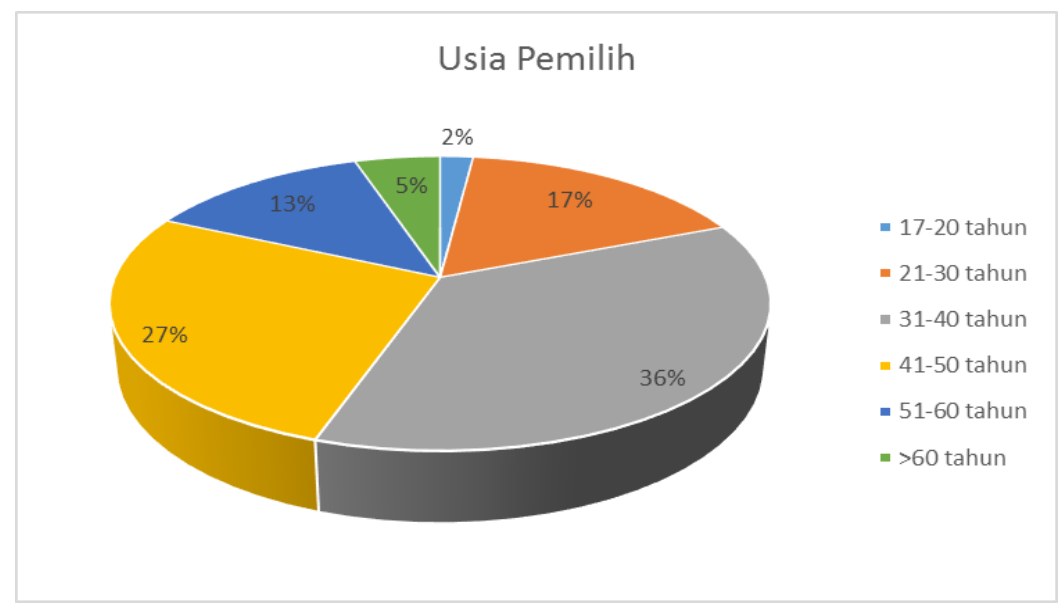

Gambar 1. Persentase usia pemilih

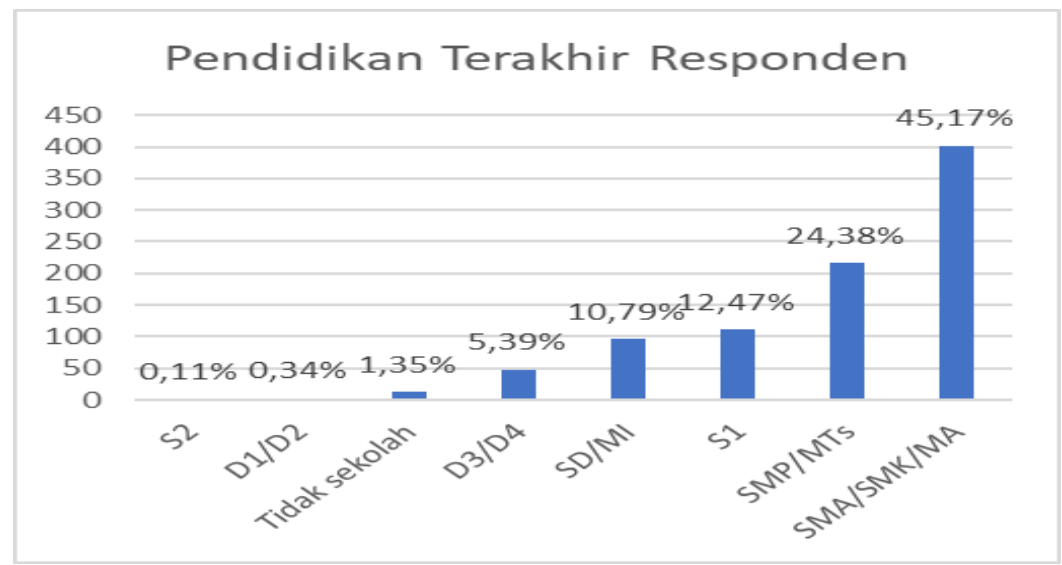

Gambar 2. Persentase pendidikan terakhir pemilih 


\section{Munawar dkk.}

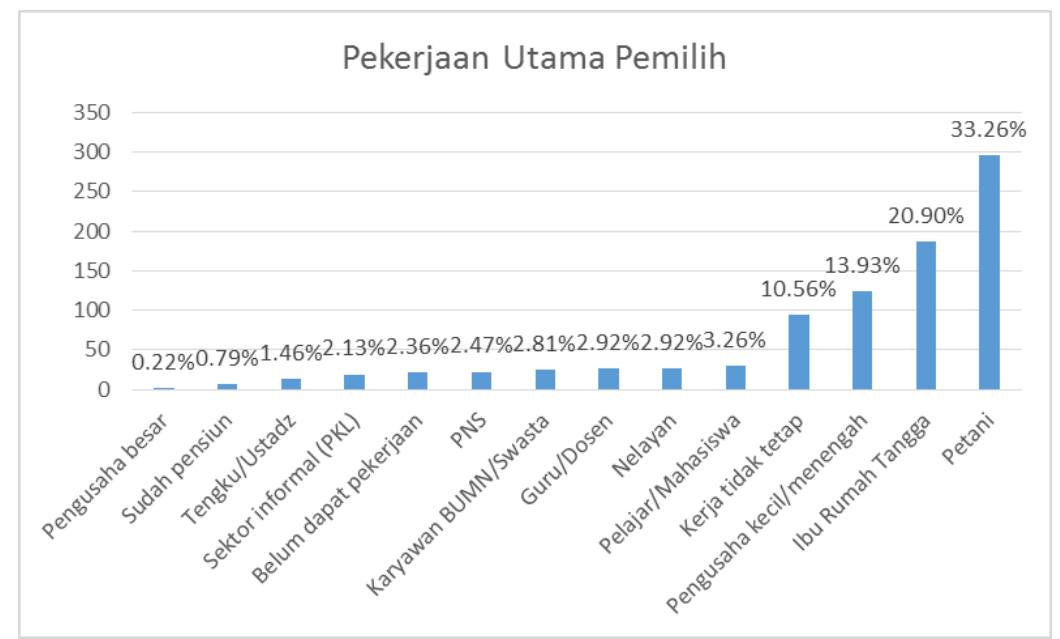

Gambar 3. Persentase pekerjaan utama pemilih

Gambar 3 menjelaskan bahwa sebagian besar pekerjaan utama pemilih adalah petani $(33,26 \%)$ dan ibu rumah tangga (20,90\%), pengusaha kecil/menengah $(13,93 \%)$, dan kerja tidak tetap $(10,56 \%)$. Selanjutnya pekerjaan pemilih lainnya sebesar $21,35 \%$. Hampir setengah pemilih (49\%) memilih kandidat bupati/wakil bupati B. Pasangan calon A dipilih sebanyak 37\% pemilih. Selanjutnya pasangan calon $C$ dan D masing-masing dipilih oleh $9 \%$ dan $5 \%$ pemilih.

Gambar 5 menjelaskan bahwa faktor yang paling menarik dari kandidat bupati/wakil bupati bagi pemilih adalah dekat dengan rakyat (F3) dengan persentase 21,24\%, berpengalaman dalam pemerintahan (F5) sebesar 16,85\%, memiliki rekam jejak yang bagus (F1) sebesar 13,71\%, memiliki komitmen terhadap ekonomi kerakyatan (F4) sebesar 13,26\%, visi, misi, dan program yang yang bagus (F6) sebesar 12,58\%, taat beragama (F2) sebesar 10,67\%, dan faktor lainnya (F7) sebesar 11,69\%.

\section{Pilihan Masyarakat Terhadap Kandidat} Bupati/Wakil Bupati
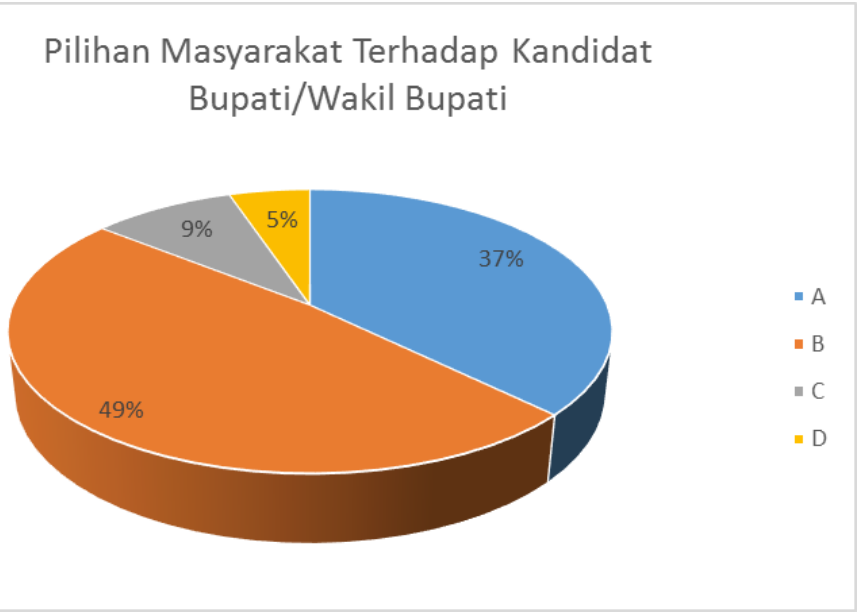

Gambar 4. Pilihan masyarakat terhadap kandidat bupati/wakil bupati 


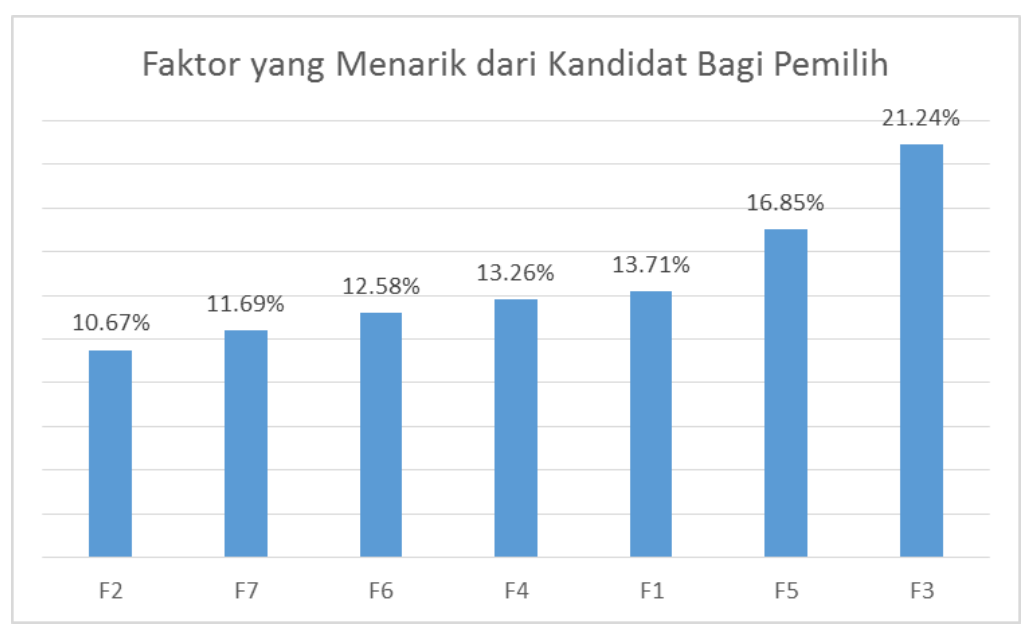

Gambar 5. Faktor yang menarik dari kandidat bagi pemilih

\section{UJI KHI-KUADRAT}

Uji Khi-kuadrat dilakukan untuk melihat ada atau tidaknya hubungan antara faktor-faktor yang mempengaruhi pilihan masyarakat terhadap pasangan calon yang menjadi pilihannya $(Y)$. Faktor-faktor tersebut terdiri dari usia pemilih $\left(X_{1}\right)$, pendidikan terakhir pemilih $\left(X_{2}\right)$, pekerjaan utama pemilih $\left(X_{\mathrm{a}}\right)$, dan alasan yang menjadi faktor pemilih memilih pasangan calon $\left(X_{4}\right)$. Dengan demikian, tulisan ini terdapat 4 pengujian dengan Khi-kuadrat. Hipotesis yang diuji adalah $H_{0}$ : tidak terdapat hubungan antara $X_{1}$ dan $Y$ melawan $H_{1}$ : terdapat hubungan antara $X_{1}$ dan $Y$ (Mattjik dan Sumertajaya, 2011) dengan $l=1,2,3,4$.

Pengujian Khi-kuadrat pertama dilakukan untuk melihat ada atau tidak ada hubungan antara usia pemilih $\left(X_{1}\right)$ dan pasangan calon yang dipilihnya $(Y)$. Hasil dari kuesioner, dari 17 pemilih yang berusia dalam kategori 1, 4 orang di antaranya memilih pasangan calon A, 10 orang memilih pasangan calon B, dan 3 lainnya memilih pasangan calon C. Pasangan calon A dipilih oleh 332 orang. Usia pemilih terbagi dalam 6 kategori. Jumlah pemilih pasangan calon A ini berasal dari kategori 1 hingga 6 berturut-turut sebesar 4, 52, 124, 91, 45, dan 16 orang. Kategori 1 hingga 6 berturut-turut merupakan kategori usia 17-20 tahun, 21-30 tahun, 31-40, 41-50 tahun, 51-60 tahun, dan usia di atas 60 tahun yang disimbulkan dengan $U_{1}$ hingga $U_{6}$.

Tabel 1. Nilai harapan untuk pengujian I

\begin{tabular}{|c|c|c|c|c|c|c|c|c|c|}
\hline \multirow{2}{*}{ Usia } & \multicolumn{2}{|c|}{$A$} & \multicolumn{2}{|c|}{ B } & \multicolumn{2}{|c|}{ C } & \multicolumn{2}{|c|}{$D$} & \multirow{2}{*}{ Jumlah } \\
\hline & $o_{i j}$ & $E_{i f i}$ & $o_{i j i}$ & $E_{i j}$ & $o_{i j i}$ & $E_{\mathrm{ij}}$ & $O_{i f}$ & $E_{i j}$ & \\
\hline$\overline{U_{1}}$ & 4 & 6,34 & 10 & 8,23 & 3 & 1,55 & 0 & 0,88 & 17 \\
\hline$U_{2}$ & 52 & 56,33 & 76 & 73,12 & 12 & 13,74 & 11 & 7,80 & 151 \\
\hline$U_{3}$ & 124 & 120,49 & 146 & 156,42 & 34 & 29,40 & 19 & 16,69 & 323 \\
\hline$U_{4}$ & 91 & 89,16 & 123 & 115,74 & 19 & 21,75 & 6 & 12,35 & 239 \\
\hline$U_{5}$ & 45 & 43,27 & 56 & 56,18 & 6 & 10,56 & 9 & 6,00 & 116 \\
\hline$U_{6}$ & 16 & 16,41 & 20 & 21,31 & 7 & 4,00 & 1 & 2,27 & 44 \\
\hline Jumlah & 332 & & 431 & & 81 & & 46 & & 890 \\
\hline
\end{tabular}

Nilai harapan untuk pasangan calon A yang dipilih oleh pemilih berusia dalam kategori 1 adalah sekitar 6,34 yang diperoleh dari jumlah pemilih yang berusia dalam kategori 1 yaitu 17 dikali dengan jumlah pemilih pasangan A yaitu 332 kemudian dibagi dengan total pemilih yaitu 890. Hal yang sama juga dilakukan untuk perhitungan 23 nilai harapan lainnya. Nilai harapan ini disajikan pada Tabel 1.

Perhitungan statistik uji $\chi^{2}=\left(\sum_{i=1}^{6} \sum_{j=1}^{4}\left(O_{i j}-E_{i j}\right)^{2}\right) / E_{i j} \quad$ (Spiegel, 1996) dilakukan dengan mensubstitusikan nilai-nilai pada Tabel 1. Nilai $\chi^{2}$ yang diperoleh adalah 17,994 . Sedangkan $\chi^{2}$ tabel adalah $\chi_{a[6-1)(4-1)}^{2}=\chi_{0,05,15}^{2}=24,996$. Hasil perhitungan ini memberikan keputusan bahwa $H_{0}$ tidak dapat ditolak. Keputusan ini memberikan kesimpulan bahwa tidak terdapat 
hubungan antara usia pemilih dan pasangan calon yang dipilihnya dengan tingkat kepercayaan 95\%. Jika dilihat dari p-value yang dihasilkan yaitu sebesar 0,263 maka untuk mengatakan ada hubungan di antara keduanya, tingkat kepercayaan harus direndahkan sampai sekitar 73,7\%. Hasil dari pengujian keseluruhan dirangkum dalam Tabel 2.

Tabel 2. Hasil pengujian dari 4 hipotesis

\begin{tabular}{|c|c|c|c|c|c|c|}
\hline Uji & $b$ & Derajat Bebas & $\chi^{2}$ & $\chi_{\mathbb{R}_{(b-1)(k-1)}^{2}}^{2}$ & $p$-value & Keputusan \\
\hline I & 6 & 15 & 17,994 & 24,996 & 0,263 & Terima $H_{0}$ \\
II & 8 & 21 & 39,228 & 32,671 & 0,009217 & Tolak $H_{0}$ \\
III & 14 & 39 & 49,860 & 54,572 & 0,1141 & Terima $H_{0}$ \\
IV & 7 & 18 & 445,69 & 28,869 & $<2,2 \times 1016$ & Tolak $H_{0}$ \\
\hline
\end{tabular}

Keputusan tolak $H_{0}$ diperoleh dari pengujian II dan IV. Hal ini berarti bahwa pilihan masyarakat terhadap pasangan calon kepala daerah berkaitan dengan pendidikan terakhir pemilih dan faktor yang menarik dari pasangan calon yang dipilih. Pemilih dengan tingkat pendidikan tertentu akan memilih pasangan calon tertentu pula. Pemilih dengan alasan faktor tertentu yang menarik dari pasangan calon juga akan memilih pasangan tertentu.

Dua faktor lain yaitu usia pemilih dan pekerjaan utama pemilih tidak berhubungan secara langsung dengan pasangan calon yang dipilihnya. Pasangan calon tertentu dipilih oleh pemilih yang selang usianya berbeda-beda. Pasangan calon tertentu juga dipilih oleh pemilih yang mempunyai latar belakang pekerjaan yang tidak sama.

\section{ANALISIS KORESPONDENSI}

Hasil pengujian Khi-kuadrat menunjukkan bahwa faktor atau variabel yang mempengaruhi pemilih dalam memilih pasangan calon kepala daerahnya adalah pendidikan terakhir pemilih $\left(X_{2}\right)$ dan faktor yang menarik dari pasangan calon kepala daerah $\left(X_{4}\right)$. Kedua variabel bebas ini diambil untuk analisis korespondensi berganda. Tabel matriks Burt dibuat untuk kedua variabel bebas tersebut dan variabel respons $(Y)$.

Dua akar ciri (nilai inersia) pertama diperoleh persentase proporsi sebesar 21,529\%. Hal ini menunjukkan bahwa grafik dua dimensi yang dihasilkan dari analisis korespondensi berganda ini hanya mampu menjelaskan variabilitas data asal sebesar 21,529\% inersia total. Proporsi pada setiap dimensi yaitu pada dimensi 1 menjelaskan variabilitas sebesar $12,075 \%$ dan dimensi 2 menjelaskan variabilitas sebesar 9,454\%. Persentase untuk masing-masing nilai inersia, proporsi yang mampu dijelaskan, dan proporsi kumulatif disajikan pada Tabel 4.

Tabel 3. Tabel matriks Burt

\begin{tabular}{|c|c|c|c|c|c|c|c|c|c|c|c|c|c|c|c|}
\hline \multirow{2}{*}{ Pilihan } & \multicolumn{8}{|c|}{ Pendidikan Terakhir } & \multicolumn{7}{|c|}{ Faktor Menarik } \\
\hline & $\mathrm{P} 1$ & $\mathrm{P} 2$ & P3 & P4 & P5 & P6 & P7 & P8 & $\mathrm{F} 1$ & $\mathrm{~F} 2$ & F3 & F4 & F5 & F6 & F7 \\
\hline A & 38 & 89 & 154 & 0 & 13 & 37 & 0 & 1 & 14 & 73 & 30 & 24 & 143 & 24 & 24 \\
\hline B & 42 & 96 & 196 & 1 & 26 & 62 & 0 & 8 & 80 & 6 & 123 & 83 & 7 & 70 & 62 \\
\hline $\mathrm{C}$ & 11 & 24 & 34 & 1 & 3 & 5 & 1 & 2 & 15 & 2 & 30 & 7 & 0 & 11 & 16 \\
\hline $\mathrm{D}$ & 5 & 8 & 18 & 1 & 6 & 7 & 0 & 1 & 13 & 14 & 6 & 4 & 0 & 7 & 2 \\
\hline
\end{tabular}

Hasil korespondensi berganda ditampilkan pada suatu titik grafik 2 dimensi. Grafik tersebut digambarkan melalui titik-titik koordinat. Letak dari masing-masing kategori pada dimensi 1 dan dimensi 2 didasarkan pada masing-masing nilai massa dan inersianya (Rencher, 2002). Nilai massa diperoleh dari hasil perkalian antara matriks korespondensi dan matriks kolom yang elemen-elemennya adalah 1 . Nilai inersia menunjukkan kontribusi setiap titik koordinat pada kedua dimensi (Jonshon dan Wichern, 1988).

Plot korespondensi berganda untuk variabel pilihan masyarakat kepada pasangan calon dengan variabel pendidikan terakhir pemilih dan variabel faktor yang menarik dari pasangan calon dibentuk berdasarkan koordinat pada Tabel 5. Gambar 6 untuk melihat kategori yang 
berdekatan dari titik-titik koordinat antara pilihan masyarakat kepada pasangan calon dan pendidikan terakhir pemilih dan faktor yang menarik dari pasangan calon.

Tabel 4. Nilai Inersia, proporsi yang mampu dijelaskan, dan proporsi kumulatif

\begin{tabular}{|c|c|c|c|}
\hline Dimensi & Nilai Inersia & Proporsi Inersia (\%) & Proporsi Kumulatif (\%) \\
\hline 1 & 0,564 & 10,574 & 10,574 \\
2 & 0,443 & 8,311 & 18,885 \\
3 & 0,412 & 7,725 & 26,610 \\
4 & 0,375 & 7,031 & 33,641 \\
5 & 0,367 & 6,877 & 40,518 \\
6 & 0,360 & 6,747 & 47,265 \\
7 & 0,352 & 6,600 & 53,862 \\
8 & 0,333 & 6,252 & 60,114 \\
9 & 0,323 & 6,060 & 66,174 \\
10 & 0,315 & 5,904 & 72,078 \\
11 & 0,307 & 5,752 & 77,831 \\
12 & 0,286 & 5,356 & 83,186 \\
13 & 0,285 & 5,340 & 88,526 \\
14 & 0,265 & 4,965 & 93,491 \\
15 & 0,238 & 4,455 & 97,946 \\
16 & 0,110 & 2,054 & 100,000 \\
\hline
\end{tabular}

Tabe1 5. Dimensi 1 dan dimensi 2 dari setiap kategori

\begin{tabular}{|c|c|c|c|}
\hline Variabel & $\begin{array}{c}\text { Kode } \\
\text { Kategori }\end{array}$ & Dimensi 1 & Dimensi 2 \\
\hline \multirow{4}{*}{$\begin{array}{l}\text { Pilihan } \\
\text { Kandidat }\end{array}$} & A & $-1,161$ & $-0,115$ \\
\hline & $\mathrm{B}$ & 0,734 & $-0,252$ \\
\hline & $\mathrm{C}$ & 0,770 & 0,473 \\
\hline & $\mathrm{D}$ & 0,140 & 2,364 \\
\hline \multirow{8}{*}{$\begin{array}{l}\text { Pendidikan } \\
\text { Terakhir }\end{array}$} & P1 & $-0,042$ & 0,939 \\
\hline & $\mathrm{P} 2$ & $-0,166$ & 0,269 \\
\hline & P3 & $-0,046$ & $-0,405$ \\
\hline & $\mathrm{P} 4$ & 0,716 & 4,243 \\
\hline & P5 & 0,169 & 1,393 \\
\hline & $\mathrm{P} 6$ & 0,244 & $-0,652$ \\
\hline & $\mathrm{P} 7$ & 1,817 & $-0,697$ \\
\hline & P8 & 1,617 & 0,635 \\
\hline \multirow{7}{*}{$\begin{array}{c}\text { Faktor yang } \\
\text { menarik dari } \\
\text { Pasangan } \\
\text { Kandidat }\end{array}$} & F1 & 0,710 & 0,588 \\
\hline & $\mathrm{F} 2$ & $-1,231$ & 1,751 \\
\hline & F3 & 0,586 & 0,150 \\
\hline & $\mathrm{F} 4$ & 0,487 & $-0,703$ \\
\hline & F5 & $-1,592$ & $-0,797$ \\
\hline & F6 & 0,487 & $-0,289$ \\
\hline & F7 & 0,446 & $-0,303$ \\
\hline
\end{tabular}


Gambar 6 menjelaskan bahwa untuk kandidat A, masyarakat yang memilihnya berlatar belakang pendidikan SMP/MTs (P2). Faktor yang menarik dari kandidat A adalah karena kandidat A telah berpengalaman di bidang pemerintahan (F5) dan kandidat A taat beragama (F2). Kandidat B akan dipilih oleh dominan masyarakat karena 4 faktor, yaitu memiliki kedekatan atau sering berinteraksi dengan rakyat (F3), berkomitmen terhadap ekonomi kerakyatan (F4), faktor visi, misi, dan program bagus (F6), dan faktor lainnya (F7), serta dipilih oleh masyarakat yang memiliki latar belakang pendidikan SMP/MTs (P2), SMA/SMK/MA (P3), dan S1 (P6).

Kandidat C, dipilih oleh masyarakat yang tidak sekolah (P8) atau berpendidikan terakhir D3/D4 (P5). Faktor yang menarik dari kandidat C adalah karena memiliki rekam jejak bagus (F1) dan dekat dengan rakyat (F3). Kandidat D akan dipilih oleh masyarakat secara luas yang memiliki latar belakang pendidikan SD/MI (P1) dan D3/D4 (P5). Kandidat D tidak memiliki karakteristik tertentu yang menjadi faktor menarik untuk dipilih. Semua kandidat dipilih oleh D1/D2 (P4) dan S2 (P7) secara merata. Artinya P4 dan P7 dimiliki oleh ke-empat kandidat yang mengikuti pilkada.

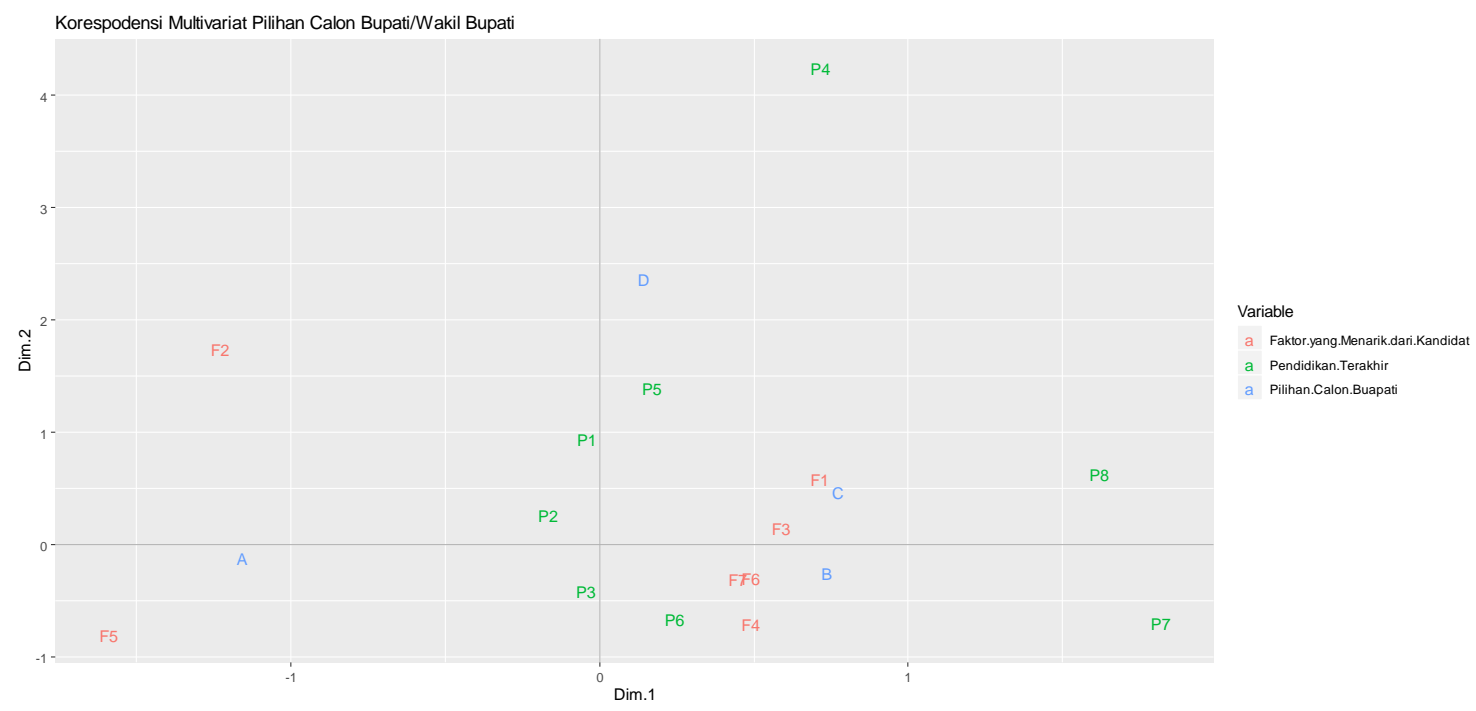

Gambar 6. Plot korespondensi berganda

\section{SIMPULAN}

Data yang dianalisis berasal dari 890 responden dan pasangan calon kepala daerah yang menjadi pilihan adalah sebanyak 4 pasangan calon. Faktor-faktor yang mempengaruhi pilihan masyarakat terhadap pilihan pasangan calon adalah pendidikan terakhir pemilih (masyarakat) dan faktor yang menarik dari pasangan calon. Dua faktor lainnya yaitu usia pemilih dan pekerjaan utama pemilih tidak berhubungan dengan pilihan masyarakat terhadap pasangan calon.

Analisis korespondensi berganda memberikan kesimpulan bahwa kandidat A dipilih oleh masyarakat karena berpengalaman di bidang pemerintahan dan taat beragama. Kandidat B dipilih oleh masyarakat dengan status pendidikan terakhir SMP/MTs, SMA/SMK/MA, dan S1 serta dipilih karena memiliki kedekatan atau sering berinteraksi dengan rakyat, berkomitmen terhadap ekonomi kerakyatan, faktor visi, misi, dan program bagus, dan faktor lainnya seperti pengadaan program bantuan untuk pertanian, madrasah, dan lain-lain. Kandidat C dipilih oleh masyarakat karena dekat dengan rakyat dan memiliki rekam jejak yang baik. Sementara kandidat D akan dipilih oleh masyarakat yang memiliki status pendidikan terakhir D1/D2 dan S2. 


\section{DAFTAR PUSTAKA}

Jonshon, A. and Wichern, W. D. 1988. Applied Multivariate Statistical Analysis. Prentice - Hall International Inc. New Jersey.

Kesuma, Z. M., Rusdiana, S., Rusyana, A., Rahayu, L., dan Rosadi, R. 2019. Aplikasi Analisis Korespondensi Berganda terhadap Status Gizi Remaja di Kota Banda Aceh. Buletin Penelitian Kesehatan, Vol. 47, No. 1, Hal. 47-54. Badan Penelitian dan Pengembangan Kesehatan. Jakarta.

Marzuki dan Hafnani. 2014. Kajian tentang Jumlah Kuadrat dan Hasil Kali dalam Analisis Varians Multivariat. Jurnal Gradien, Vol. 10, No. 2, p. 996-999. FMIPA Universitas Bengkulu. Bengkulu.

Mattjik, A. A dan Sumertajaya I. M. 2011. Sidik Peubah Ganda dengan Menggunakan SAS. Departemen Statistika IPB. Bogor.

Rencher, C. A. 2002. Methods of Multivariate Analysis Second Edition. A John Wiley and Sons, Inc. Publication. New Jersey.

Spiegel, R. M. 1996. Teori dan Soal-soal Statistika Edisi Kedua. Erlangga. Jakarta. 